DOI https://doi.org/10.30525/978-9934-588-81-5-1.43

\title{
ОСОБЛИВОСТІ РАННЬОГО АТОПІЧНОГО СТАТУСУ НА ТЛІ ХАРЧОВОЇ АЛЕРГІЇ У ДИТИНИ 1 РОКУ 6 МІСЯЦІВ. КЛІНІЧНИЙ ВИПАДОК
}

\author{
Ріга О. О. \\ доктор медичних наук, \\ професор кафедри педіатрї та неонатології № 1 \\ Харківський національний медичний університет \\ Омельченко О. В. \\ кандидат медичних наук, \\ доиент кафедри педіатрї та неонатології № 1 \\ Харківський начіональний медичний університет \\ Орлова Н. В. \\ аспірант кафедри педіатрії та неонатології № 1 \\ Харківський начіональний медичний університет \\ Арасланова Т. $\mathbf{P .}$ \\ студентка 6 курсу \\ Харківський начіональний медичний університет \\ Горбунова I. B. \\ студентка 6 курсу \\ Харківський національний медичний університет \\ м. Харків, Україна
}

Атопічний дерматит (АД) посідає особливе місце в структурі алергічних захворювань, негативно впливає на якість життя та потребує довготривалого лікування [1]. У той же час поширеність доведеної харчової алергії в розвинених країнах Західної Свропи серед дітей віком до 14 років становить 10-20\% [2]. У дітей АД вперше проявляється до 6 місяців у $45 \%$ випадків, впродовж першого року життя - у $60 \%$, до 5 років - у $80 \%$ випадків [3]. У той же час поширеність доведеної харчової алергії в розвинених країнах серед дітей першого року життя становить 6-8\%, а в підлітковому віці - 2-4\%. Перші ознаки захворювання маніфестують вже у перші два місяці життя. Приблизно $20 \%$ батьків вважають, що в їхньої дитини є харчова алергія, яка розпочинається з харчової сенсебілізації [4]. Харчові антигени, які впливають на дитину у період новонародженності можуть бути важливими 
сенсебілізуючими факторами [5]. Розуміння причин формування атопічного статусу, застосування раціонального харчування сприяє профілактиці алергії у дітей з групи ризику.

Метою даного клінічного випадку є демонстрація можливих причин формування атопічного статусу у дитини та відображення сучасних принципів діагностики та лікування.

Наводимо власне спостереження.

Дівчина В., 1 рік та 6 місяців госпіталізована зі скаргами на біль у животі, випорожнення неоформлені до 3-4 разів на добу, шкірну висипку, сповільнення збільшення маси тіла. 3 анамнезу відомо, що дитина від другої вагітності, яка протікала із загрозою викидню. Під час вагітності мати отримала 2 курси антибактеріальної терапії з приводу хронічного пієлонефриту. Пологи на 40-му тижні вагітності, фізіологічні. При народженні маса тіла 3100 г., довжина 50 см. Оцінка за шкалою Апгар 8 та 9 балів на 1 та 5 хвилині життя відповідно. На грудному вигодовуванні була перші 4 тижні, потім був введений прикорм молочною сумішшю. У дитини з народження відмічалися неспокій, який виникав після кожного годування, здуття живота та коліки. За перший місяць маса тіла збільшилася на 310 г. Матері рекомендовано виключити з раціону молочні продукти (вживала до двох стаканів молока на добу). На другому місяці життя у дитини з'явилася алергічна висипка на шкірі. Встановлений клінічний діагноз: «Атопічний дерматит, малюкова розповсюджена форма, тяжкий перебіг». Педіатром рекомендовано переведення на високогідралізовану суміш на основі білків молочної сироватки та розпочати введення прикорму з безмолочної гіпоалергенної каші, овочевого пюре (кабачок, кольорова капуста, броколі, гарбуз), м'ясного пюре (індик, кролик), фруктового пюре (яблуко, груша, слива). Після корекції харчування розповсюдженість алергічної висипки у дитини була повністю усунена. У віці 18-ти місяців батьки самостійно додали в раціон відварену телятину, жовток та через місяць стан дитини погіршився, з'явлилися еритематозно-уртикарні елементи на обличчі, тулубі, кінцівках з вираженим свербіжем, біль у животі, випорожнення зі слизом. Застосування антигістамінних препаратів та засобів зовнішньої терапії не забезпечили бажаного терапевтичного ефекту.

Сімейний анамнез: у батька бронхіальна астма, у матері медикаментозна алергія. Обєктивно: стан дитини тяжкий за основним захворюванням. Дівчинка емоціонально лабільна, плаксива, непокоїть свербіж шкіри. Шкірні покриви бліді, сухі, підшкірно-жирова клітковина виражена слабко, тургор тканин знижений. На шкірі тулуба та кінцівок 
відмічаються еритематозно-сквамозні елементи на фоні гіперемії та набряку, що утворюють ділянки кірочок та лусочок. Маса дитини складає 10.3 кг, зріст - 78 см., фізіологічний розвиток дитини низький, гармонійний. Психомоторний розвиток відповідає віковій нормі. Лімфовузли не збільшені, носове дихання вільне. Перкуторно визначається ясний легеневий звук. Аускультативно: у легенях дихання проводиться в усі відділи, везикулярне, хрипів немає. Тони серця звучні, ритмічні. Живіт м'який, безболісний при пальпації. Печінка виступає 3-під краю реберної дуги на 2 см., селезінка не пальпується. Нестійкі, розріджені випорожнення до 6 разів на добу, з домішками слизу.

Додаткові методи дослідження: у клінічному аналізі крові - помірна еозинофілія до 8\%. У копрограмі: виражена стеаторея, помірна амілорея, помірна кількість слизу, поодинокі лейкоцити. Рівень фекального кальпротектину в межах референтних значень і складає 55,01 мкг / г (норма 53-119.0 мкг / г). В біохімічному аналізі загальний білок знижений до 50 г / л (норма - 56 - 75 г / л), підвищення АЛТ до 0.98 ммоль / год / л (норма 0,1-0,68 ммоль / год / л), гіпохолестеринемія - 2, 9 ммоль / л (норма 3,5-5,2 ммоль / л), рівень загального імуноглобуліну Е 95 МО / мл (норма від 0 до $90 \mathrm{MO} /$ мл). Виявлено специфічні імуноглобуліни $\operatorname{IgE-антитіла~до~жовтка~курячого~яйця,~білку~курячого~яйця,~яловичини,~}$ до коров'ячого молока. Целіакія була виключена на підставі отриманих результатів дослідження: EMA Ig A 1: 4 (N <1: 5), anti- tissue transglutaminase, tTG IgA, 7 Од (N <10,0 Од / мл); IgG 6 Од / мл ( $\mathrm{N}<10,0$ Од / мл), Ig G (АГА) - 10 Од / мл. (N 12,5 Од / мл). При проведенні УЗД органів черевної порожнини, виявлено реактивні зміни підшлункової залози, підвищення пневмотизації кишківника.

Консультації дерматолога: Атопічний дерматит, малюкова розповсюджена форма, тяжкий перебіг, період загострення. Рекомендовані місцеві глюкокортикостероїди, зволожуючі і пом'якшуючі засоби.

Клінічний діагноз: Атопічний дерматит, малюкова розовсюджена форма, важкий перебіг, період загострення. Харчова алергія.

Враховуючи анамнез захворювання та результати обстеження, дитині було призначено дієту з виключенням молока і молочних продуктів, яловичини, телятини, яєць; рекомендації дерматолога. Для корекції нутрітивного статусу додатково рекомендована лікувальна суміш на основі амінокислот для дітей від 1 року до 10 років.

На тлі проведеного лікування стан дитини покращився: значно зменшилися поширеність і прояви шкірних висипань, нормалізувався стілець, прибавка в масі тіла 150 г (за 5 днів). 
Через 7 місяців при обстеженні виявлено поліпшення стану пацієнтки у вигляді усунення висипань на шкірі, відсутність скарг на біль в животі, позитивна динаміка масо-ростових показників.

Даний клінічний випадок демонструє раннє формування атопічного статусу з розвитком алергічної хвороби на тлі обтяженого алергійного анамнезу. Дитині в 2 місяці життя був встановлений діагноз атопічного дерматиту, причинами розвитку якого були антигени, одержувані з молоком матері. Дівчинка переведена на високогідролізовані суміші на основі білків молочної сироватки. Визначено продукти, що викликають утворення специфічних IgE антитіл у дитини. Призначення правильного раціону, що містить гіпоалергенні продукти, та лікувальної суміші на основі амінокислот дозволили усунути симптоми і в динаміці нормалізувати масо-ростові і лабораторні показники.

\section{Література:}

1. Schneider L. Study of the Atopic March: Development of Atopic Comorbidities // Pediatr Dermatol. 2016, vol. 33, № 4, p. 388-398.

2. Hochwallner H, Schulmeister U, Swoboda I, et al. Infant milk formulas differ regarding their allergenic activity and induction of T-cell and cytokine responses. Allergy. 2017;72(3):416-424. doi: 10.1111 / all.12992.

3. Ohba F. Efficacy of a novel phosphodiesterase inhibitor, E6005, in patients with atopic dermatitis: An investigatorblinded, vehicle-controlled study // J. Dermatolog. Treat. 2016, vol. 27, № 5, p. 467-472.

4. Osborn DA, Sinn JK, Jones LJ. Infant formulas containing hydrolysed protein for prevention of allergic disease and food allergy. Cochrane Database Syst Rev. 2017;(3):CD003664. doi: 10.1002/ 14651858.CD003664.pub4.

5. Alduraywish SA, Lodge CJ, Campbell B, et al. The march from early life food sensitization to allergic disease: a systematic review and metaanalyses of birth cohort studies. Allerg y. 2016;71(1): 77-89. doi: 10.1111/all.12784. 